\title{
CAG REPEAT NUMBER IN THE ANDROGEN RECEPTOR GENE AND PROSTATE CANCER
}

Madjunkova $\mathrm{S}^{1}$, Eftimov $\mathrm{A}^{2}$, Georgiev $\mathrm{V}^{3}$, Petrovski $\mathrm{D}^{3}$, Dimovski $\mathrm{AJ}^{2}$, PlaseskaKaranfilska $\mathrm{D}^{1}, *$

*Corresponding: Author: Professor Dr. Dijana Plaseska-Karanfilska, Macedonian Academy of Sciences and Arts, Research Center for Genetic Engineering and Biotechnology "Georgi D. Efremov", Av. Krste Misirkov 2, POB 428, 1000 Skopje, Republic of Macedonia; Tel.: +389-2-3235-410; Fax: +389-2-3115434; E-mail: dijana@manu.edu.mk

\section{ABSTRACT}

Prostate cancer (PC) is the second leading cause of cancer deaths in men. The effects of androgens on prostatic tissue are mediated by the androgen receptor (AR) gene. The 5' end of exon 1 of the AR gene includes a polymorphic CAG triplet repeat that numbers between 10 to 36 in the normal population. The length of the CAG repeats is inversely related to the transactivation function of the AR gene. There is controversy over association between short CAG repeat numbers in the AR gene and PC. This retrospective case-control study evaluates the possible effect of short CAG repeats on the AR gene in prostate cancer risk in Macedonian males. A total of 392 male subjects, 134 PC patients, 106 patients with benign prostatic hyperplasia (BPH) and 152 males from the general Macedonian population were enrolled in this study. The CAG repeat length was determined by fluorescent polymerase chain reaction (PCR) amplification of exon1 of the AR gene followed by capillary electrophoresis (CE) on a genetic analyzer. The mean repeat length in PC patients was $21.5 \pm 2.65$, in controls $22.28 \pm 2.86(p=$ $0.009)$ and in BPH patients $22.1 \pm 2.52(p=0.038)$.

1. Macedonian Academy of Sciences and Arts, Research Center for Genetic Engineering and Biotechnology "Georgi D. Efremov", Skopje, Republic of Macedonia

2. Faculty of Farmacy, Farmacogenetic laboratory, Skopje Republic of Macedonia

Faculty of Medicine, Skopje, Republic of Macedonia
Short CAG repeats $(<19)$ were found in $21.64 \%$ of PC patients vs. $9.43 \%$ in BPH patients $(p=0.0154)$. We also found an association of low Gleason score $(<7)$ with short CAG repeat $(<19)$ in PC patients $(p$ $=0.0306)$, and no association between the age at diagnosis of $\mathrm{PC}$ and $\mathrm{BPH}$ and $\mathrm{CAG}$ repeat length. These results suggest that reduced $\mathrm{CAG}$ repeat length may be associated with increased prostate cancer risk in Macedonian men.

Keywords: Prostrate cancer (PC); Androgen receptor (AR) gene; $\mathrm{CAG}$ repeat; Benign prostatic hyperplasia $(\mathrm{BPH})$

\section{INTRODUCTION}

Prostate cancer (PC) is the second leading cause of cancer deaths in men and is the most common male-specific cancer in most Western countries [1-5]. An expanding body of epidemiological data suggests several risk factors that predispose to PC development (for example, advanced age, positive family history, African ancestry and potentially ethnicity) [6], but the etiology of PC remains poorly understood. However, involvement of genetic and environmental factors, may also contribute to the ethnic differences in incidence rates [7-9]. The development and progression of prostate tumors are influenced by androgens [10]. The effects of androgens on prostatic tissue are mediated by the androgen receptor (AR) through the AR-androgen complex, stimulating transcription and expression of a 
cascade of androgen-responsive genes and genes involved in the cell cycle control [11].

The AR is a ligand-activated nuclear transcription factor encoded by the $A R$ gene, which spans more than $90 \mathrm{~kb}$ of the genomic DNA on the $\mathrm{X}$ chromosome (Xq11-12). The gene consists of eight exons that encode four functional domains of $A R$ for DNA binding, ligand binding and transcriptional regulation [12]. Exon 1 encodes the $\mathrm{N}$-terminal (transactivation) domain that controls its transcriptional activity. The 5' end of this exon 1 includes a CAG polymorphic trinucleotide repeat that codes for a polyglutamine tract in the $\mathrm{N}$-terminal domain [13]. The triplet repeat numbers between 8 and 36 in the normal population [14].

The length of the CAG repeats is inversely related to the transactivation function of the $A R$ gene so that shorter CAG repeats increase the transactivation activity [15]. Many studies have focused on establishing an association of CAG repeat with increased risk of developing PC. In these, shorter repeat lengths have been associated with increased risk of PC [14,16-18], but this finding has not been consistent [19-21]. The ethnic variation in the CAG repeat variation in the $A R$ gene suggests that this may have a role in the substantial racial difference in PC risk [22-25]. In this study, we have examined the possible effect of short CAG repeats in the $A R$ gene on PC risk in Macedonian males.

\section{MATERIALS AND METHODS}

Materials. We enrolled 134 PC patients, 106 patients with benign prostatic hyperplasia (BPH) and 152 males from the general Macedonian population for this study. Informed consent was obtained from all and the study was approved by the Ethic Committees of the Macedonian Academy of Sciences and Arts and Faculty of Pharmacy, Skopje, Republic of Macedonia. Prostate cancer patients and those with BPH were recruited from the Department of Urology, Medical Faculty, Skopje, Republic of Macedonia and were referred to the Pharmacogenetic Laboratory, Faculty of Pharmacy, Skopje, Republic of Macedonia. Only those with histopathologically-confirmed diagnoses were included. The mean ages of the PC and $\mathrm{BPH}$ patients were $68.19 \pm 7.36$ and $69.72 \pm .55$ years, respectively. Males from the general pop- ulation were selected at the Research Center for Genetic Engineering and Biotechnology "Georgi D. Efremov," Macedonian Academy of Sciences and Arts, Skopje, Republic of Macedonia to produce a control sample that was age-matched to the samples of $\mathrm{PC}$ and $\mathrm{BPH}$ patients.

Methods. Genomic DNA was extracted from EDTA whole blood following a standard phenol/ chloroform method. The CAG repeat number was determined by fluorescent polymerase chain reaction (PCR) amplification of exon 1 of AR gene. Approximately 50-100 ng genomic DNA was subjected to 35 cycles of PCR amplification using fluorescently-labeled forward primer 5'-(HEX) TCC AGA ATC TGT TCC AGA GCG TGC-3' and unlabeled reverse prime ${ }^{5}$ '-GCT GTG AAG GTT GCT GTT CCT CA-3'. The PCR amplification was performed as follows: 45 seconds at $94^{\circ} \mathrm{C}, 30$ seconds at $62^{\circ} \mathrm{C}$ and $1 \mathrm{~min}$. at $72^{\circ} \mathrm{C}$. The size of the PCR product was determined by capillary electrophoresis (CE) on an ABI PRISM ${ }^{\mathrm{TM}} 3130$ Genetic Analyzer (Applied Biosystems, Foster City, CA, USA). The number of CAG repeats predicted by the Genescan software v.6 (Applied Biosystems) was compared with the actual CAG repeats determined by direct dideoxy terminator cycle sequencing using the BigDye Terminator Sequencing Kit v1.0 (Applied Biosystems) in male DNA samples as described previously [26].

Statistical Analyses. The frequency of the CAG repeat alleles was compared between the studied groups using the $\chi 2$ and Fisher's exact tests. Values were expressed as mean \pm standard deviation (SD). Differences in the mean of (CAG)n length between different groups of patients (PC, BPH) vs. controls were tested by the independent samples $t$-test using SPSS 14.0 (SPSS Chicago, IL, USA), after checking for normal distribution. The association of different CAG repeat length was tested at different cutoff points: $\leq 19, \leq 20, \leq 21, \leq 22$ and $>22$. Statistical significance was defined as $p<0.05$.

\section{RESULTS}

The range of CAG repeats among patients with $\mathrm{PC}$ and with BPH, and in control subjects was 1529, 17-30 and 14-30, respectively. The frequency of CAG repeats in PC and BPH patients and control subjects are given in Figure 1. 

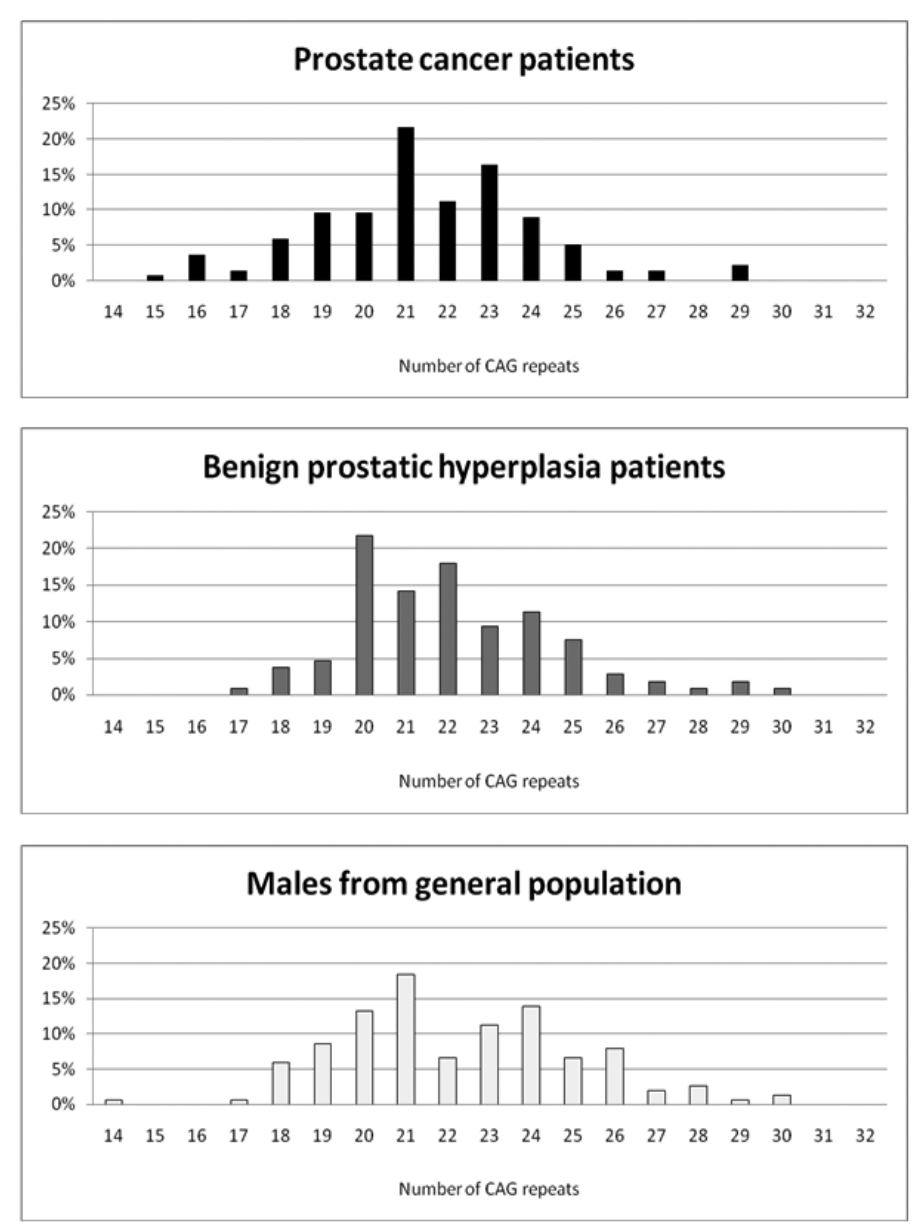

Figure 1. Distribution of CAG repeats in exon 1 of the AR gene in PC patients, BHP patients and males from the general population.

The mean repeat length in the PC patients was $21.5 \pm 2.65$, in $\mathrm{BPH}$ patients $22.1 \pm 2.52(p=0.038)$ and in the control subjects $22.28 \pm 2.86(p=0.009)$.
Figure 2 shows the distribution of the short CAG repeats in the studied groups. The association of the CAG repeat lengths at different cut-off points with PC patients is shown in Table 1. We found a significantly higher percentage of short CAG repeats $(\leq 19)$ in PC patients $(21.64 \%)$ than in $\mathrm{BPH}$ patients $(9.43 \%)(p=0.0154)$.

Table 2 shows the association of early $(\leq 65$ years) and advanced ( $>65$ years) age at diagnosis of $\mathrm{PC}$ and $\mathrm{BPH}$ patients with different $\mathrm{CAG}$ repeat length of the AR gene. We found no association between the repeat length and age at diagnosis of either group. The distribution of PC and BPH diagnosed in these age groups was similar at the different cut-off point of CAG repeat length.

The association of CAG repeats at different cut-off points with a Gleason score was analyzed in 110 PC patients (Table 3). A Gleason score of $<7$ was found in $35(31.82 \%)$, and a Gleason score of $\geq 7$ in $75(68.18 \%)$. In the PC patients with repeat number of $\leq 19$, we found a significantly higher percentage $(34.3 \%, p=0.0306)$ of low grade tumors (Gleason score $<7$ ) against $16.0 \%$ that were high grade PC tumors (Gleason score $\geq 7$ ). The similar distribution of low and high grade tumors was present at cut-off points of CAG repeats of $\leq 21(p=0.0624)$ and $C A G$ repeats of $\leq 22(p=0.0868)$ but these differences are not statistically significant. Relative to the repeat length of $\leq 21$ and a Gleason score of $<7$, the odds ratio (OR) for the $\leq 22$ was $2.15,95 \%$ CI (95\% confidence interval) (0.887-5.211) and for the CAG repeat length of $>22$ it was $0.465,95 \%$ CI (0.192-1.128).

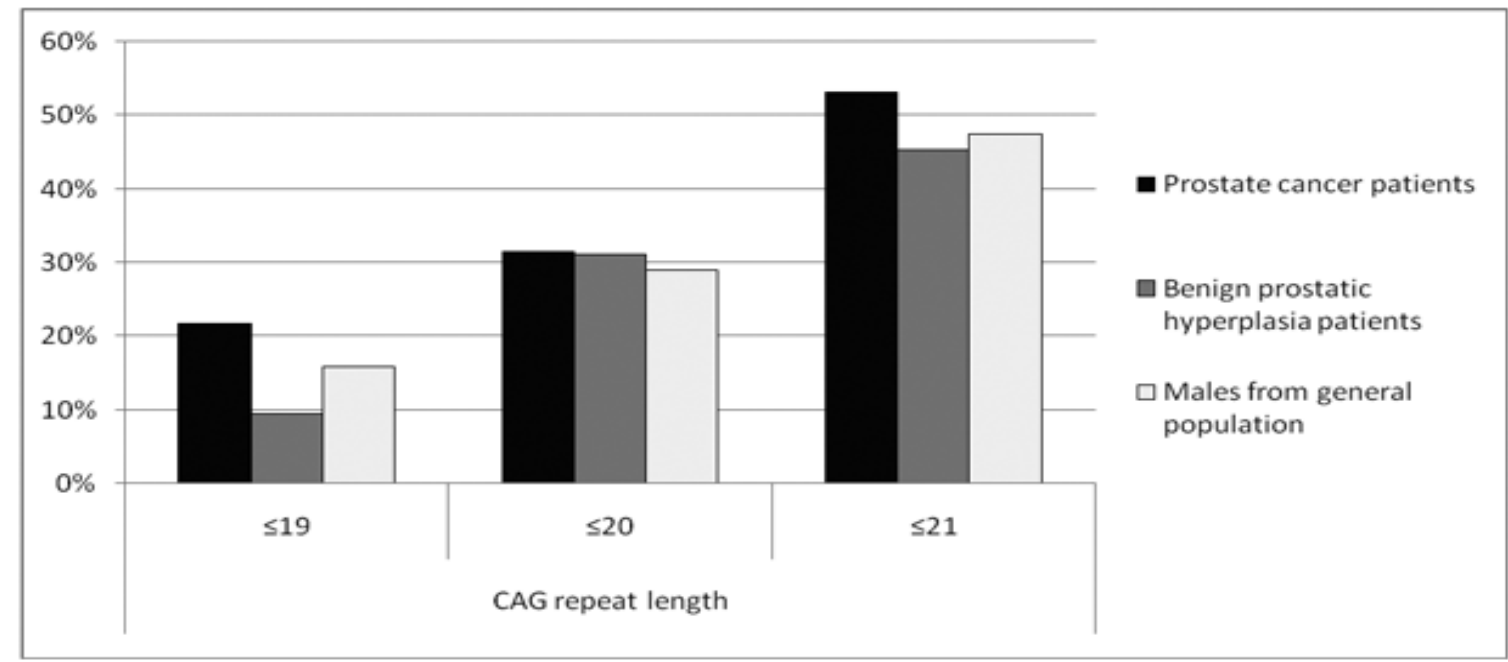

Figure 2. Distribution of short CAG repeats in exon 1 of the AR gene in the three studied groups. 
Table 1. Association of CAG repeat lengths at different cut-off points in the studied groups.

\begin{tabular}{|c|c|c|c|c|c|c|}
\hline & \multicolumn{5}{|c|}{ CAG Repeat Lengths } & \\
\hline Studied Groups & $\leq 19$ & $\leq 20$ & $\leq 21$ & $\leq 22$ & $>22$ & Total \\
\hline PC patients, $n(\%)$ & $29(21.6)$ & $42(31.3)$ & $71(53.0)$ & $86(64.2)$ & $48(35.8)$ & 134 \\
\hline BPH patients, $n(\%)$ & $10(9.4)$ & $33(31.1)$ & $48(45.3)$ & $67(63.2)$ & $39(36.8)$ & 106 \\
\hline OR $(95 \%$ CI $)$ & $2.531(1.173-5.461)$ & $1.010(0.583-1.750)$ & $1.362(0.817-2.271)$ & $1.043(0.614-1.771)$ & $0.959(0.565-1.628)$ & \\
\hline$p$ value & 0.0154 & 1.0000 & 0.2360 & 0.8764 & 0.8764 & \\
\hline GP males, $n(\%)$ & $24(15.8)$ & $44(29.0)$ & $72(47.4)$ & $82(54.0)$ & $70(46.1)$ & 152 \\
\hline OR (95\% CI) & $1.473(0.809-2.682)$ & $1.121(0.676-1.859)$ & $1.252(0.876-1.994)$ & $1.529(0.950-2.461)$ & $0.654(0.406-1.052)$ & \\
\hline$p$ value & 0.2037 & 0.6593 & 0.3431 & 0.0794 & 0.0794 & \\
\hline
\end{tabular}

PC: prostate cancer; BPH: benign prostatic hyperplasia; GP: general population; the BPH $p$ value is of statistical significance (0.05).

Table 2. Association of CAG repeat lengths at different cut-off points, by age at diagnosis.

\begin{tabular}{|c|c|c|c|c|c|c|}
\hline & \multicolumn{5}{|c|}{ CAG Repeat Lengths } & \\
\hline Studied Groups & $\leq 19$ & $\leq 20$ & $\leq 21$ & $\leq 22$ & $>22$ & Total \\
\hline PC patients, $n$ (\%) & 27 (21.6) & $39(31.7)$ & $67(54.5)$ & $81(65.9)$ & $42(34.2)$ & $123(100.0)$ \\
\hline$<65$ years & $7(17.5)$ & $10(25.0)$ & $20(50.0)$ & $25(62.5)$ & $15(37.5)$ & $40(32.5)$ \\
\hline$>65$ years & $20(24.1)$ & $29(34.9)$ & $47(56.6)$ & $56(57.5)$ & $27(32.5)$ & $83(67.5)$ \\
\hline OR (95\% CI) & $0.668(0.256-1.742)$ & $0.621(0.266-1.446)$ & $0.766(0.359-1.632)$ & $0.804(0.365-1.767)$ & $1.244(0.566-2.736)$ & \\
\hline$p$ value & 0.4077 & 0.2671 & 0.4894 & 0.5861 & 0.5861 & \\
\hline BPH patients, $n$ (\%) & $9(22.0)$ & $33(31.7)$ & $48(54.5)$ & $67(65.9)$ & $39(34.2)$ & $106(100.0)$ \\
\hline$<65$ years & $2(6.3)$ & $9(28.1)$ & $13(40.6)$ & $20(62.5)$ & $12(37.5)$ & $32(30.2)$ \\
\hline$>65$ years & $7(9.5)$ & $24(32.4)$ & $35(47.3)$ & $47(63.5)$ & $27(36.5)$ & $74(69.8)$ \\
\hline OR (95\% CI) & $0.638(0.125-3.255)$ & $0.815(0.328-2.028)$ & $0762(0.329-1.766)$ & $0.957(0.406-2.258)$ & $1.044(0.443-2.463)$ & \\
\hline$p$ value & 0.5863 & 0.6602 & 0.5264 & 1.0000 & 1.0000 & \\
\hline
\end{tabular}

PC: prostate cancer; BPH: benign prostatic hyperplasia.

Table 3. Association of CAG repeat lengths at different cut-off points by Gleason score in PC patients.

\begin{tabular}{|c|c|c|c|c|c|c|}
\hline & \multicolumn{5}{|c|}{ CAG Repeat Lengths } & \\
\hline & $\leq 19$ & $\leq 20$ & $\leq 21$ & $\leq 22$ & $>22$ & Total \\
\hline PC patients, $\boldsymbol{n}$ (\%) & $24(21.8)$ & $35(31.8)$ & $58(52.7)$ & $69(62.7)$ & $41(37.3)$ & $110(100.0)$ \\
\hline Gleason $<7$ & $12(34.3)$ & $14(40.0)$ & $23(65.7)$ & $26(74.3)$ & $9(25.7)$ & $35(31.8)$ \\
Gleason $\geq 7$ & $12(16.0)$ & $21(28.0)$ & $35(46.7)$ & $43(57.3)$ & $32(42.7)$ & $75(68.2)$ \\
\hline OR (95\% CI) & $2.739(1.079-6.955)$ & $1.714(0.738-3.985)$ & $2.190(0.953-5.036)$ & $2.150(0.897-5.211)$ & $0.465(0.192-1.128)$ & \\
p value & $\mathbf{0 . 0 3 0 6}$ & 0.2082 & 0.0624 & 0.0868 & 0.0868 & \\
\hline
\end{tabular}

PC: prostate cancer; the bold letters indicate a statistical significance $(p<0.05)$.

\section{DISCUSSION}

The hypothesis that variation in transcriptional activity of the AR related to polymorphic CAG repeats [27] influences prostate carcinogenesis [28], has been tested in many studies. The results have not been in full agreement, some finding moderateto-significant association of short $\mathrm{CAG}$ repeats with increased PC risk, others failing to confirm this.

Our results suggest that a shorter CAG repeat length $(\leq 19)$ is associated with an increased risk of PC. This agrees with previous reports that short $\mathrm{CAG}$ repeat lengths in the $\mathrm{AR}$ gene predisposes to PC $[14,29,30]$. However others, studying FrenchGerman populations [31] and North American pop- ulations [20,32], have reported no such association.

The association between PC and increasing age is very strong [33]. In our study the same proportion of patients with PC and with BPH (about 2/3) was diagnosed at $>65$ years, and we found no association between short $\mathrm{CAG}$ repeat length and age at diagnosis. This supports the importance of age as an independent risk factor for PC and BPH [34].

To test if short CAG repeats may predispose to more aggressive forms of PC [14,35], we performed a case analysis according to Gleason score and found an association between repeat length $\leq 19$ and low grade PC tumors (Gleason score $<7$ ). For advanced disease, we observed a suggestive lower risk with fewer CAG repeats, unlike in the Physicians' 
Health Study [36], which showed a monotonically increasing risk with decreasing number of CAG repeats for advanced cases. The possible explanation is that androgens may influence the stage and grade of PC independently, and the increased androgenic stimulation in PC patients with lower CAG repeat length and subsequently higher AR activity, may prevent the dedifferentiation of the prostate epithelium in the nascent tumor [37]. This needs to be clarified and further investigated to determine the influence of androgens on differentiation status in cases that are restricted to uniform stage.

We found that CAG repeat length was not significantly different in BPH patients than in controls $(p=0.9166)$ but was significantly different between PC and BPH $(p=0.038)$. This agrees with previous studies and the Prostate Cancer Prevention Trial $[38,39]$. Our results suggest the possibility that the risk of malignancy is not higher in BPH patients than in controls, and that BPH is an independent entity and is not a precancerous state [40]. We conclude that short CAG repeats $(\leq 19)$ may be associated with increased PC risk in Macedonian men and that our results provide potential tools to assist in prediction strategies for this important disease.

\section{REFERENCES}

1. Crawford ED. Epidemiology of prostate cancer. Urology. 2003; 62(6): 3-12.

2. Gronberg H. Prostate cancer epidemiology. Lancet. 2003; 361(9360): 859-864.

3. Haas GP, Sakr WA. Epidemiology of prostate cancer. CA Cancer J Clin. 1997; 47(5): 273-287.

4. Scosyrev E, Messing EM, Mohile S, Golijanin D, Wu G. Prostate cancer in the elderly: frequency of advanced disease at presentation and disease-specific mortality. Cancer. 2011; doi: 10.1002/cncr.26392. [Epub ahead of print].

5. Nelson KA, Witte JS. Androgen receptor CAG repeats and prostate cancer. Am J Epidemiol. 2002; 155(10): 883-890.

6. Mittal RD, Mishra D, Mandhani AK. Role of an an drogen receptor gene polymorphism in development of hormone refractory prostate cancer in Indian population. Asian Pac J Cancer Prev. 2007; 8(2): 275-278.

7. Cotter MP, Gern RW, Ho GY, Chang RY, Burk RD. Role of family history and ethnicity on the mode and age of prostate cancer presentation. Prostate. 2002; 50(4): 216-221.

8. Du XL, Fang S, Coker AL, Sanderson M, Aragaki C, Cormier JN, Xing Y, Gor BJ, Chan W. Racial disparity and socioeconomic status in association with survival in older men with local/regional stage prostate carcinoma: findings from a large communitybased cohort. Cancer. 2006; 106(6): 1276-1285.

9. Schaid DJ. The complex genetic epidemiology of prostate cancer. Hum Mol Genet. 2004; 13(Spec No 1): R103-121.

10. Feldman BJ, Feldman D. The development of andro gen-independent prostate cancer. Nat Rev Cancer. 2001; 1(1): 34-45.

11. Lu S, Tsai SY, Tsai MJ. Regulation of androgendependent prostatic cancer cell growth: androgen regulation of CDK2, CDK4, and CKI p16 genes. Cancer Res. 1997; 57(20): 4511-4516.

12. Montgomery JS, Price DK, Figg WD. The androgen receptor gene and its influence on the development and progression of prostate cancer. J Pathol. 2001; 195(2): 138-146.

13. Edwards A, Hammond HA, Jin L, Caskey CT, Chakraborty R. Genetic variation at five trimeric and tetrameric tandem repeat loci in four human population groups. Genomics. 1992; 12(2): 241-253.

14. Giovannucci E, Stampfer MJ, Krithivas K, Brown M, Dahl D, Brufsky A, Talcott J, Hennekens CH, Kantoff PW. The CAG repeat within the androgen receptor gene and its relationship to prostate cancer. Proc Natl Acad Sci USA. 1997; 94(7): 3320-3323.

15. Chamberlain NL, Driver ED, Miesfeld RL. The length and location of $\mathrm{CAG}$ trinucleotide repeats in the androgen receptor $\mathrm{N}$-terminal domain affect transactivation function. Nucleic Acids Res .1994; 22(15): 3181-3186.

16. Hardy DO, Scher HI, Bogenreider T, Sabbatini P, Zhang ZF, Nanus DM, Catterall JF. Androgen receptor CAG repeat lengths in prostate cancer: correlation with age of onset. J Clin Endocrinol Metab. 1996; 81(12): 4400-4405.

17. Stanford JL, Just JJ, Gibbs M, Wicklund KG, Neal CL, Blumenstein BA, Ostrander EA. Polymorphic repeats in the androgen receptor gene: molecular markers of prostate cancer risk. Cancer Res. 1997; 57(6): 1194-1198.

18. Irvine RA, Yu MC, Ross RK, Coetzee GA. The CAG and GGC microsatellites of the androgen receptor gene are in linkage disequilibrium in men with prostate cancer. Cancer Res. 1995; 55(9): 1937-1940.

19. Zeegers MP, Kiemeney LA, Nieder AM, Ostrer H. How strong is the association between CAG and GGN repeat length polymorphisms in the androgen receptor gene and prostate cancer risk? Cancer Epidemiol Biomarkers Prev. 2004; 13(11): 1765-1771.

20. Price DK, Chau CH, Till C, Goodman PJ, Baum CE, Ockers SB, English BC, Minasian L, Parnes HL, Hsing AW, Reichardt JK, Hoque A, Tangen CM, Kristal AR, Thompson IM, Figg WD. Androgen receptor $\mathrm{CAG}$ repeat length and association with prostate cancer risk: results from the prostate cancer prevention trial. J Urol. 2010; 184(6): 2297-2302.

21. Lindstrom S, Ma J, Altshuler D, Giovannucci E, Riboli E, Albanes D, Allen NE, Berndt SI, Boeing H, 
Bueno-de-Mesquita HB, Chanock SJ, Dunning AM, Feigelson HS, Gaziano JM, Haiman CA, Hayes RB, Henderson BE, Hunter DJ, Kaaks R, Kolonel LN, Le Marchand L, Martinez C, Overvad K, Siddiq A, Stampfer M, Stattin P, Stram DO, Thun MJ, Trichopoulos D, Tumino R, Virtamo J, Weinstein SJ, Yeager M, Kraft P, Freedman ML. A large study of androgen receptor germline variants and their relation to sex hormone levels and prostate cancer risk. Results from the National Cancer Institute Breast and Prostate Cancer Cohort Consortium. J Clin Endocrinol Metab. 2010; 95(9): E121-E127.

22. Mishra D, Thangaraj K, Mandhani A, Kumar A, Mittal R. Is reduced CAG repeat length in androgen receptor gene associated with risk of prostate cancer in Indian population? Clin Genet. 2005; 68(1): 55-60.

23. Hakimi JM, Schoenberg MP, Rondinelli RH, Piantadosi S, Barrack ER. Androgen receptor variants with short glutamine or glycine repeats may identify unique subpopulations of men with prostate cancer. Clin Cancer Res. 1997; 3(9): 1599-1608.

24. Hsing AW, Gao YT, Wu G, Wang X, Deng J, Chen YL, Sesterhenn IA, Mostofi FK, Benichou J, Chang C. Polymorphic CAG and GGN repeat lengths in the androgen receptor gene and prostate cancer risk: a population-based case-control study in China. Cancer Res. 2000; 60(18): 5111-5116.

25. Akinloye O, Gromoll J, Simoni M. Variation in CAG and GGN repeat lengths and CAG/GGN haplotype in androgen receptor gene polymorphism and prostate carcinoma in Nigerians. Br J Biomed Sci. 2011; 68(3): 138-142.

26. Plaseski T, Noveski P, Dimitrovski C, Kocevska B, Efremov GD, Plaseska-Karanfilska D. CAG Repeat number in androgen receptor gene and male infertility. BJMG. 2007; 10(1): 19-24.

27. Coetzee GA, Ross RK. Re: prostate cancer and the androgen receptor. J Natl Cancer Inst. 1994; 86(11): 872-873.

28. Ding D, Xu L, Menon M, Reddy GP, Barrack ER. Effect of a short CAG (glutamine) repeat on human androgen receptor function. Prostate. 2004; 58(1): 23-32.

29. Gu M, Dong X, Zhang X, Niu W. The CAG repeat polymorphism of androgen receptor gene and prostate cancer: a meta-analysis. Mol Biol Rep. 2011; 39(3): 2615-2624.

30. Binnie MC, Alexander FE, Heald C, Habib FK. Polymorphic forms of prostate specific antigen and their interaction with androgen receptor trinucleotide repeats in prostate cancer. Prostate. 2005; 63(4): 309-315.
31. Correa-Cerro L, Wohr G, Haussler J, Berthon P, Drelon E, Mangin P, Fournier G, Cussenot O, Kraus P, Just W, Paiss T, Cantu JM, Vogel W. (CAG)nCAA and GGN repeats in the human androgen receptor gene are not associated with prostate cancer in a French-German population. Eur J Hum Genet. 1999; 7(3): 357-362.

32. Salinas CA, Austin MA, Ostrander EO, Stanford JL. Polymorphisms in the androgen receptor and the prostate-specific antigen genes and prostate cancer risk. Prostate. 2005; 65(1): 58-65.

33. Jemal A, Siegel R, Xu J, Ward E. Cancer statistics, 2010. CA Cancer J Clin. 2010; 60(5): 277-300.

34. Polednak AP. Trends in prostate carcinoma inci dence in Connecticut (1988-1994) by age and race. Cancer. 1997; 79(1): 99-103.

35. Rodriguez-Gonzalez G, Cabrera S, RamirezMoreno R, Bilbao C, Diaz-Chico JC, Serra L, Chesa N, Cabrera JJ, Diaz-Chico BN. Short alleles of both GGN and CAG repeats at the exon-1 of the androgen receptor gene are associated to increased PSA staining and a higher Gleason score in human prostatic cancer. J Steroid Biochem Mol Biol. 2009; 113(1-2): 85-91.

36. Platz EA, Giovannucci E, Dahl DM, Krithivas K, Hennekens CH, Brown M, Stampfer MJ, Kantoff PW. The androgen receptor gene GGN microsatellite and prostate cancer risk. Cancer Epidemiol Biomarkers Prev. 1998; 7(5): 379-384.

37. Platz EA, Leitzmann MF, Rifai N, Kantoff PW, Chen YC, Stampfer MJ, Willett WC, Giovannucci E. Sex steroid hormones and the androgen receptor gene $\mathrm{CAG}$ repeat and subsequent risk of prostate cancer in the prostate-specific antigen era. Cancer Epidemiol Biomarkers Prev. 2005; 14(5): 1262-1269.

38. Bousema JT, Bussemakers MJ, van Houwelingen KP, Debruyne FM, Verbeek AL, de La Rosette JJ, Kiemeney LA. Polymorphisms in the vitamin D receptor gene and the androgen receptor gene and the risk of benign prostatic hyperplasia. Eur Urol. 2000; 37(2): 234-238.

39. Kristal AR, Price DK, Till C, Schenk JM, Neuhouser ML, Ockers S, Lin DW, Thompson IM, Figg WD. Androgen receptor CAG repeat length is not associated with the risk of incident symptomatic benign prostatic hyperplasia: results from the Prostate Cancer Prevention Trial. Prostate. 2010; 70(6): 584-590.

40. Gsur A, Preyer M, Haidinger G, Zidek T, Madersbacher S, Schatzl G, Marberger M, Vutuc C, Micksche M. Polymorphic CAG repeats in the androgen receptor gene, prostate-specific antigen polymorphism and prostate cancer risk. Carcinogenesis. 2002; 23(10): 1647-1651. 